\title{
Analysis of Influence Law of Burial Depth on Surrounding Rock Deformation of Roadway
}

\author{
Hai Wu $\mathbb{D}^{1,2}$ Xiaokang Wang $\mathbb{D}^{1,3}$ Weijian Yu, ${ }^{1}$ Weijun Wang, \\ Zizheng Zhang, ${ }^{2}$ and Gang Peng ${ }^{1}$ \\ ${ }^{1}$ School of Resources, Environment and Safety Engineering, Hunan University of Science and Technology, Xiangtan 411201, China \\ ${ }^{2}$ Work Safety Key Lab on Prevention and Control of Gas and Roof Disasters for Southern Goal Mines, \\ Hunan University of Science and Technology, Xiangtan 411201, China \\ ${ }^{3}$ Changsha Institute of Mining Research Co., Ltd., Changsha 410012, China
}

Correspondence should be addressed to Hai Wu; wuhai@hnust.edu.cn and Xiaokang Wang; wang630750@163.com

Received 30 July 2020; Revised 22 October 2020; Accepted 7 November 2020; Published 23 November 2020

Academic Editor: Richeng Liu

Copyright (C) 2020 Hai Wu et al. This is an open access article distributed under the Creative Commons Attribution License, which permits unrestricted use, distribution, and reproduction in any medium, provided the original work is properly cited.

\begin{abstract}
In order to study the influence of burial depth on the roadway deformation, the deformation data of more than 100 roadways were collected and classified. The results have shown that, in the first 5 days of new digging roadways, the surrounding rock deformation is basically not affected by the buried depth. The influence period of roadway deformation with different depths is the same, namely, the severe period (1 15 days), the mitigation period (15 35 days), and the stable period (35 50 days). With the increase in depth, the surrounding rock deformation increment of new digging roadways with a depth of $300 \sim 600 \mathrm{~m}$ is much larger than that of $600 \sim 900 \mathrm{~m}$. Within $100 \mathrm{~m}$ of the working face from the monitoring point, the deformation of mining roadways can be divided into two stages: severe impact $(10 \sim 60 \mathrm{~m})$ and stable impact $(60 \sim 100 \mathrm{~m})$. With the increase in depth, the deformation increment of the surrounding rock in the mining roadways with a depth of $600 \sim 900 \mathrm{~m}$ is much larger than that of $300 \sim 600 \mathrm{~m}$. The surrounding rock deformation increases with the increase in the width and height of roadways and gradually increases with the decrease in the strength of rock mass.
\end{abstract}

\section{Introduction}

In recent years, the mining quantity of coal resources is growing, and coal mining has been extending to the deep earth. With the increase in mining depth, the environment of "high geostress, high geothermal, high osmotic, and strong mining disturbance" has an obvious influence on the failure extent of roadway surrounding rock. As a result, the surrounding rock demonstrates a series of response problems such as discontinuous, uncoordinated large deformation, and large-scale instability [1-5]. Therefore, many scholars have conducted a large number of experimental studies on ground control of roadways and made great progress, and they put forward a series of new theories and technologies to improve the instability of roadways caused by the increase in mining depth to some extent. Bai et al. [6] monitored the deformation of the air roadway surrounding rock with a burial depth of $300 \mathrm{~m}$ and obtained that the maximum relative displacement of the roadway roof to floor and two sides were $50 \mathrm{~mm} 68 \mathrm{~mm}$, respectively. Kang et al. [7] monitored the deformation of the machine roadway surrounding rock with a burial depth of $400 \mathrm{~m}$ in Chuanjing coal mine and obtained that the maximum relative displacement of the roadway roof to floor and two sides were $110 \mathrm{~mm}$ and $105 \mathrm{~mm}$, respectively. Li et al. [8] monitored the deformation of the machine roadway surrounding rock with a burial depth of $600 \mathrm{~m}$ in Xutuan coal mine and obtained that the maximum relative displacement of the roadway roof to floor and two sides were $280 \mathrm{~mm}$ and $380 \mathrm{~mm}$, respectively. Yu et al. [9] monitored the deformation of the wind roadway surrounding rock with a burial depth of $800 \mathrm{~m}$ in Qujiang coal mine and obtained that the maximum relative displacement of the roadway roof to floor and two sides were $285 \mathrm{~mm}$ and $200 \mathrm{~mm}$, 
respectively. Wu et al. [10] monitored the deformation of the track roadway surrounding rock with a burial depth of $900 \mathrm{~m}$ in Qujiang coal mine and obtained that the maximum relative displacement of the roadway roof to floor and two sides were $350 \mathrm{~mm}$ and $360 \mathrm{~mm}$, respectively. Kang et al. [11] analyzed the influence of rock burst on the deformation and failure characteristics of the surrounding rock and revealed that to protect the integrity of surrounding rock, it is necessary to form a support stress field in the surrounding rock and reduce the stress concentration factor to give full play to the impact resistance of surrounding rock. Wang et al. [12] studied the influence of support resistance on surrounding rock deformation of the deep high-stress roadway by using Kastner and other relevant theories. They believed that the present supporting system exerted limited influences on the continuous deformation and proposed that the support concept should be transferred from deformation control to stability control to ensure even and coordinated deformation of the roadway. Bai et al. [13] analyzed the deformation and failure characteristics of mining roadway floor and proposed that the key point of floor heave control in mining roadway was to support the broken floor, increase the intensity after the peak and residual intensity, and reduce the size of the floor without support. Ma et al. [14] analyzed the influence of the formative mechanics and morphological characteristics of the plastic zone of surrounding rock on the stability of the roof and concluded that in order to ensure the roof stability, the support must have enough length and extension performance. Yu et al. [15] analyzed the failure characteristics of half coal rock roadway and believed that the support of two sides was the key, and they put forward the supporting system with "the anchor, net, cable, and beams" as the core.

Although a lot of studies have been conducted on roadway deformation at present, when coal mines turn to deep mining, the research on the failure mechanism of deep dynamic pressure roadway is still insufficient. The influence of factors, especially, such as burial depth on roadway deformation law, needs further study.

\section{Data Collection of Roadway Surrounding Rock Deformation}

By consulting the literature about the ground control of roadways, the deformation data of about 100 roadways with different buried depths were collected. These roadways have the following characteristics:

(1) In the roadways, bolt, cable, metal net, steel reinforcement ladder beam, shotcrete, and other supporting methods are generally adopted

(2) When the buried depth of roadway is less than $300 \sim 400 \mathrm{~m}$, anchor cable is not widely used and grouting support is seldom used

(3) When the buried depth of roadway exceeds $500 \mathrm{~m}$, roadway support begins to use anchor cable, grouting bolt grouting, and other supporting methods
(4) With the increase in buried depth of roadway, the supporting density of bolt and cable increases

According to the location and service period of the roadway, the surrounding rock deformation data were divided into two categories: new digging roadway deformation and mining roadway deformation.

\section{Analysis of New Digging Roadway Deformation}

3.1. Displacement of Roadway Roof to Floor. According to the burial depth and excavation time of roadways, the deformation data of new digging roadways were classified and analyzed. The scatter diagrams of surrounding rock deformation were obtained and the deformation data was fitted by a quadratic polynomial.

Figures 1 and 2 show the displacement of roof to floor on the $5^{\text {th }}$ and $15^{\text {th }}$ day after roadway excavation, respectively, 5 150 $\mathrm{mm}$ and $25 \sim 250 \mathrm{~mm}$. By curve fitting of deformation data with MATLAB, the relationship between the buried depth and the displacement of roof to floor is obtained: $y=-1.872 * 10^{-4} x^{2}+0.279 x-46.533$ and $y=-3.315 * 10^{-4} x^{2}+0.567 x-98.193$.

According to the fitting curve result (Figure 1), in the first 5 days after roadway excavation, the differences of displacement of roof to floor with different buried depths are minor. The displacement of roadway roof to floor is not affected by burial depth.

As shown in Figures 3 and 4 , on the $25^{\text {th }}$ and $35^{\text {th }}$ day after roadway excavation, the displacement of roof to floor is 25 300 $\mathrm{mm}$ and 40 330 $\mathrm{mm}$, respectively. The relationship between the buried depth and the displacement of roof to floor is obtained: $y=-4.475 * 10^{-4} x^{2}+0.793 x-143.521$ and $y=-4.561 * 10^{-4} x^{2}+0.864 x-149.702$.

Figures 5 and 6 show the displacement of roof to floor on the $45^{\text {th }}$ and $50^{\text {th }}$ day after roadway excavation, respectively, $45 \sim 380 \mathrm{~mm}$ and $50 \sim 385 \mathrm{~mm}$. The relationship between the buried depth and the displacement of roof to floor is obtained: $y=-4.338 * 10^{-4} x^{2}+0.871 x-144.119$ and $y=-4.188 * 10^{-4} x^{2}+0.86 x-137.494$.

Figure 7 is a $3 \mathrm{D}$ stereogram composed of roadway excavation time, burial depth, and roof to floor deformation velocity.

Figure 8 is the comparison diagram of roadway deformation curves obtained by fitting formulas. From Figures 7 and 8, the results are as follows:

(1) During the 1 15 days after excavation, the displacement of roof to floor with different depths increases sharply with the increase in time.

(2) During the 15 35 days after excavation, the displacement of roof to floor increases with the increase in depth, and the displacement of roof to floor with the same depth decreases gradually with the increase in time.

(3) With the increase in excavation time, the increment of deformation velocity of roof to floor decreases with the increase in depth. 


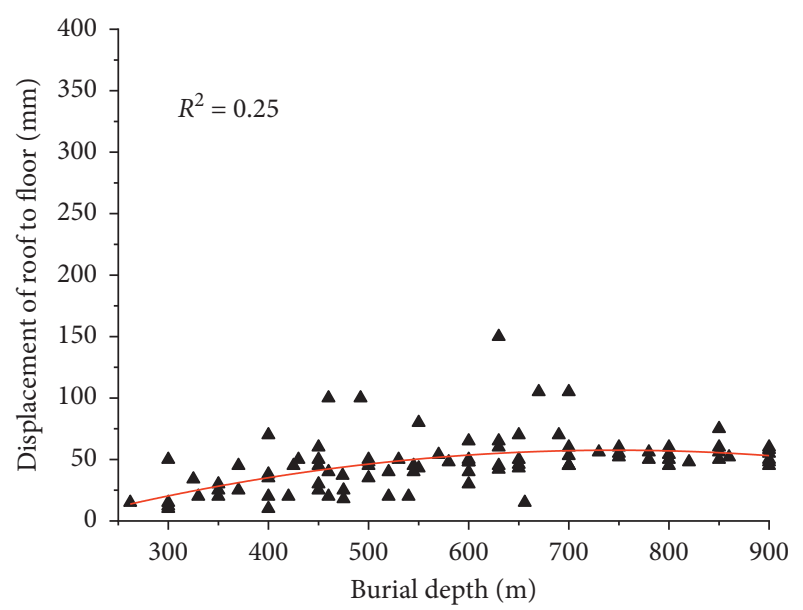

\ Displacement point - Fitting curve

Figure 1: Displacement of roof to floor ( $5^{\text {th }}$ day).

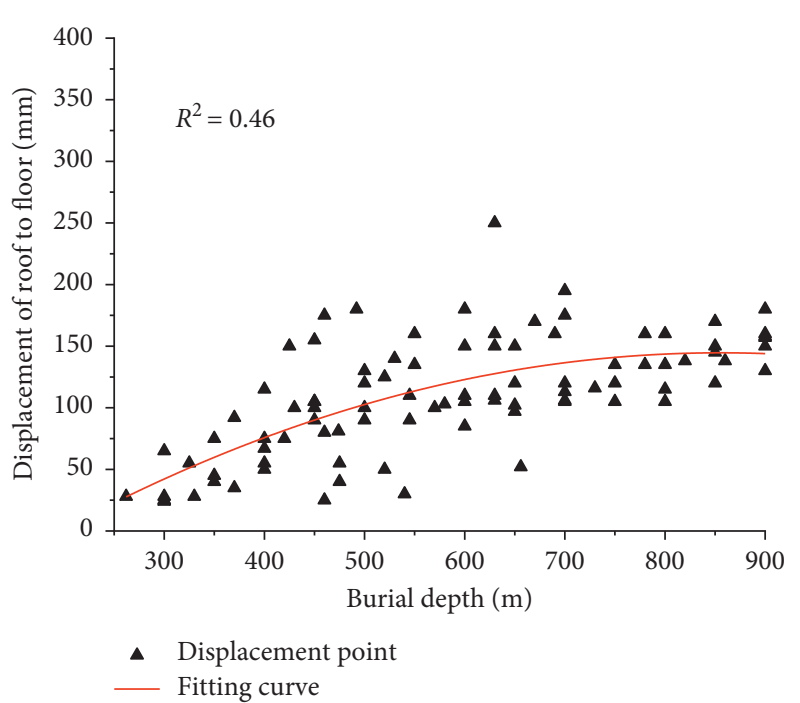

FIGURE 2: Displacement of roof to floor ( $15^{\text {th }}$ day).

(4) During the 35 50 days after excavation, the deformation velocity of roof to floor gradually decreases compared with the previous stage, and finally tends to be stable. The deformation velocity difference of roof to floor with different depths is small.

According to the quadratic polynomial of the fitting curve, the displacement of roadway roof to floor on the $50^{\text {th }}$ day after roadway excavation was calculated, as shown in Table 1.

As can be seen from Table 1, the difference value of roof to floor decreases gradually with the increase in depth. The difference value of roof to floor displacement between $300 \mathrm{~m}$ and $600 \mathrm{~m}$ buried depth is $144.9 \mathrm{~mm}$. The difference value of roof to floor displacement between $600 \mathrm{~m}$ and $900 \mathrm{~m}$ buried depth is $69.6 \mathrm{~mm}$ which is about half of the difference value between 300 and $900 \mathrm{~m}$ depth.

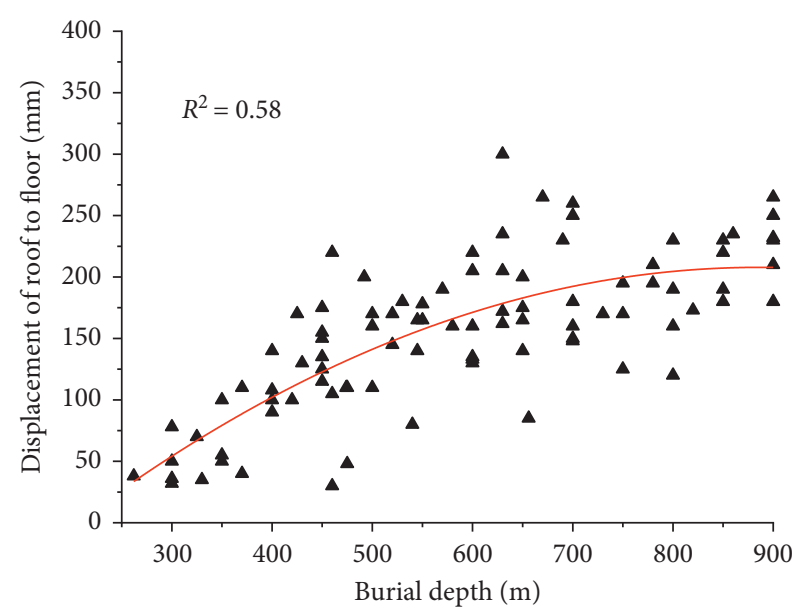

\ Displacement point

- Fitting curve

Figure 3: Displacement of roof to floor $\left(25^{\text {th }}\right.$ day).

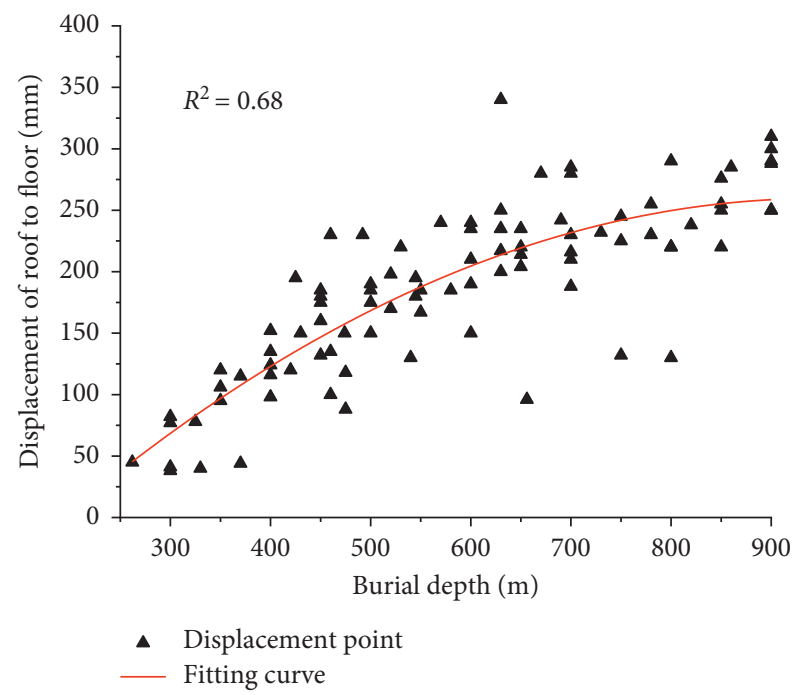

FIgURE 4: Displacement of roof to floor $\left(35^{\text {th }}\right.$ day).

3.2. Displacement of Roadway Ribs. As shown in Figures 9 and 10 , on the $5^{\text {th }}$ and $15^{\text {th }}$ days after the roadway was excavated, the displacement of two ribs is $5 \sim 140 \mathrm{~mm}$ and 20 240 mm, respectively. The relationship between the buried depth and the displacement of ribs is obtained: $y=-2.024 * 10^{-4} x^{2}+0.258 x-29.075$ $y=-3.127 * 10^{-4} x^{2}+0.461 x-38.075$.

and

According to the fitting curve (Figure 9), in the first 5 days after roadway excavation, the differences of roadway ribs displacement with different depths are minor. The displacement of roadway rib to rib is not affected by depth.

As shown in Figures 11 and 12, on the $25^{\text {th }}$ and $35^{\text {th }}$ days after the roadway was excavated, the displacement of two ribs is $45 \sim 300 \mathrm{~mm}$ and $50 \sim 340 \mathrm{~mm}$, respectively. The relationship between the buried depth and the displacement of ribs is obtained: $y=-3.721 * 10^{-4} x^{2}+0.582 x-44.935$ and $y=-3.216 * 10^{-4} x^{2}+0.58 x-32.528$. 


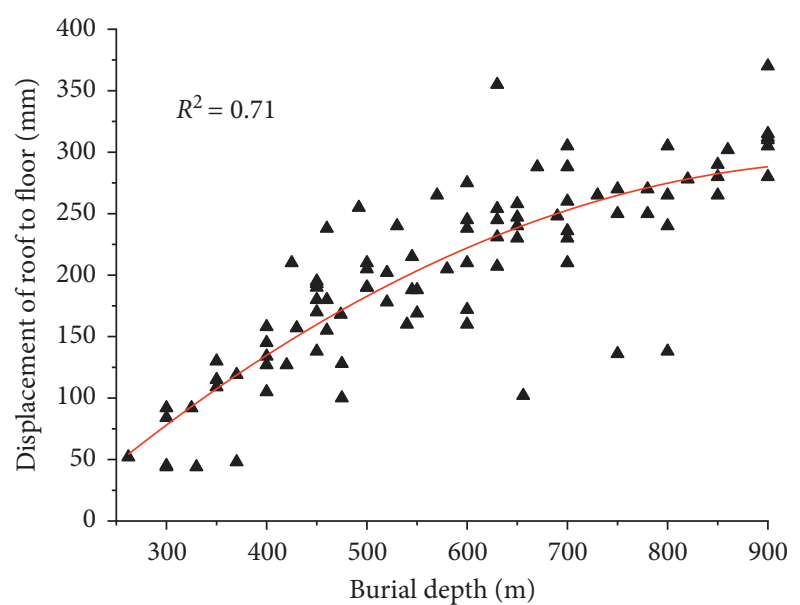

\ Displacement point

_ Fitting curve

FIgURE 5: Displacement of roof to floor $\left(45^{\text {th }}\right.$ day).

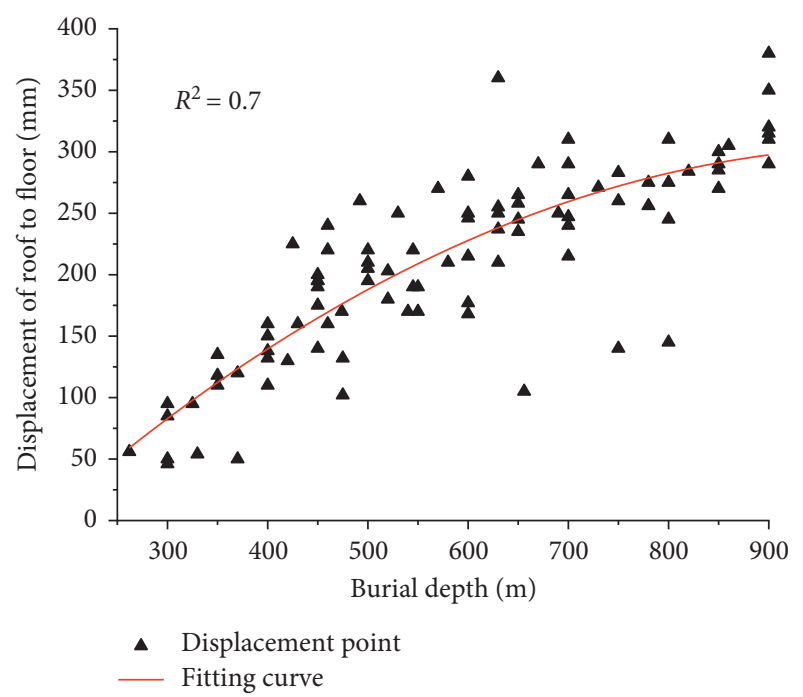

Figure 6: Displacement of roof to floor ( $40^{\text {th }}$ day).

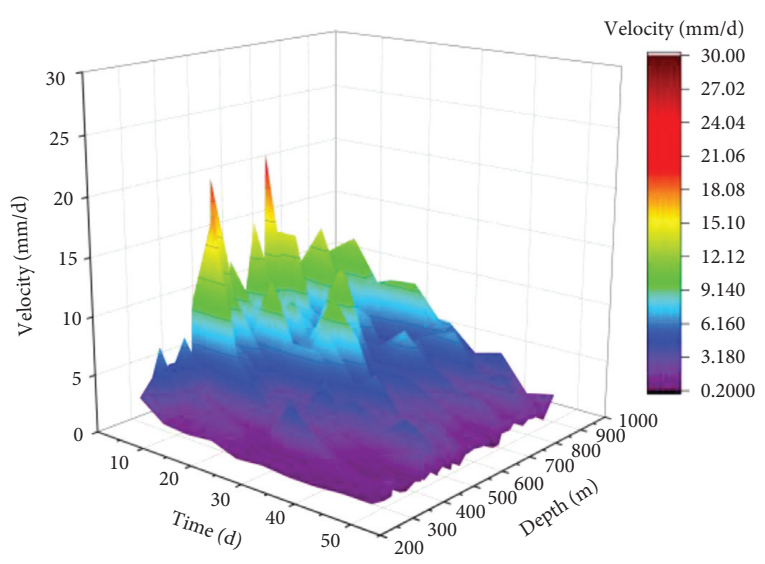

FIGURE 7: Deformation velocity of roof to floor.

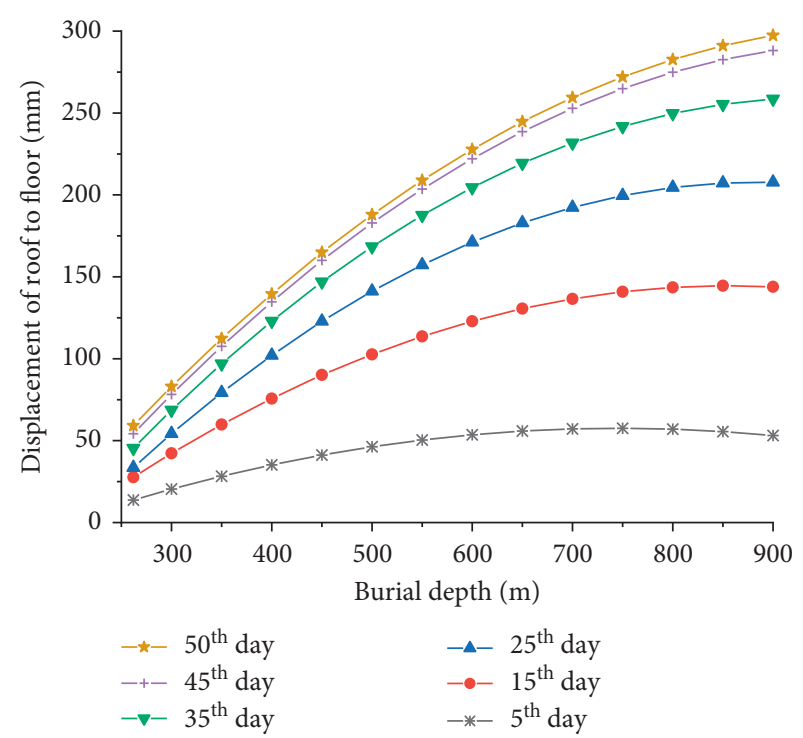

Figure 8: Comparison of displacement of roof to floor.

As shown in Figures 13 and 14, on the $45^{\text {th }}$ and $50^{\text {th }}$ days after roadway excavation, the displacement of two ribs is 50 370 $\mathrm{mm}$ and 55 375 $\mathrm{mm}$, respectively. The relationship between the buried depth and the displacement of ribs is obtained: $\quad y=-2.941 * 10^{-4} x^{2}+0.583 x-29.985 \quad$ and $y=-2.132 * 10^{-4} x^{2}+0.511 x-10.881$.

Figures 15 and 16 were obtained according to the displacement of roadway ribs at different time points. Figure 15 is a $3 \mathrm{D}$ stereogram composed of roadway excavation time, burial depth, and roadway ribs deformation velocity. Figure 16 is the comparison diagram of roadway deformation curves obtained by fitting formulas. From Figures 15 and 16, the results are as follows:

(1) During 1 15 days after excavation, the displacement of two ribs with different burial depths increases sharply with the increase in time.

(2) During 15 35 days after excavation, the displacement of roadway roof to floor increases with the increase in buried depth, and the displacement of two ribs with the same buried depth decreases gradually with the increase in time.

(3) With the increase in excavation time, the increment of deformation velocity of two ribs decreases with the increase in burial depth.

(4) During the 35 50 days after excavation, the deformation velocity of two ribs gradually decreases compared with the previous stage and finally tends to be stable. The deformation velocity difference of roadways ribs with different depths is small.

According to the quadratic polynomial of the fitting curve, the displacement of roadway ribs on the $50^{\text {th }}$ day after roadway excavation was calculated, as shown in Table 2.

As can be seen from Table 2, the difference value of ribs displacement decreases gradually with the increase in depth. The difference value between $300 \mathrm{~m}$ and $600 \mathrm{~m}$ depth is 
TABLE 1: Comparison of displacement of new digging roadway roof to floor.

\begin{tabular}{|c|c|c|c|c|c|c|c|c|c|c|c|c|}
\hline Depth (m) & 300 & & 400 & & 500 & & 600 & & 700 & & 800 & 900 \\
\hline Displacement of roof to floor (mm) & 82.8 & & 139.5 & & 187.8 & & 227.7 & & 259.3 & & 285.5 & 297.3 \\
\hline Difference value $(\mathrm{mm})$ & & 56.7 & & 48.3 & & 39.9 & & 31.6 & & 23.2 & & \\
\hline
\end{tabular}

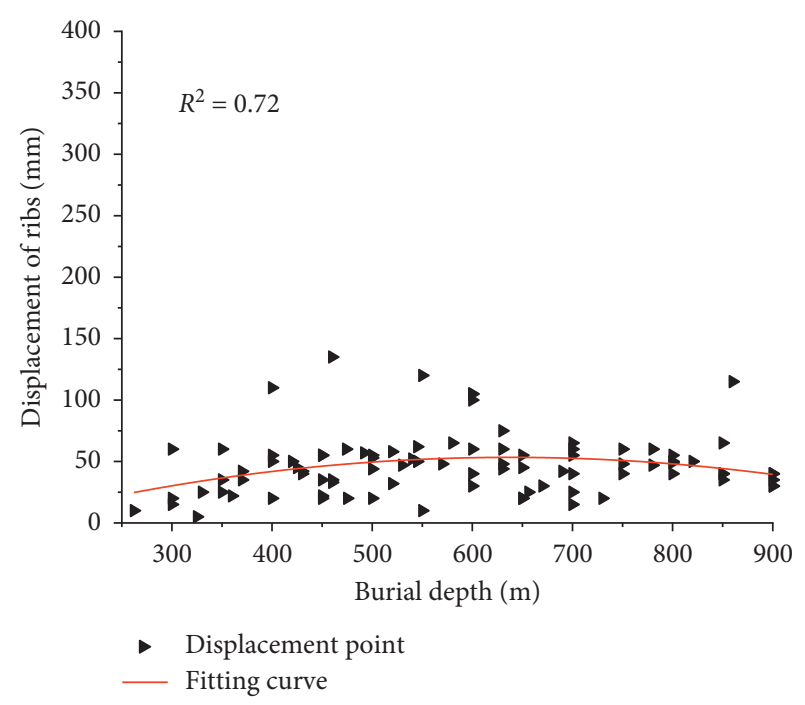

Figure 9: Displacement of ribs ( $5^{\text {th }}$ day).

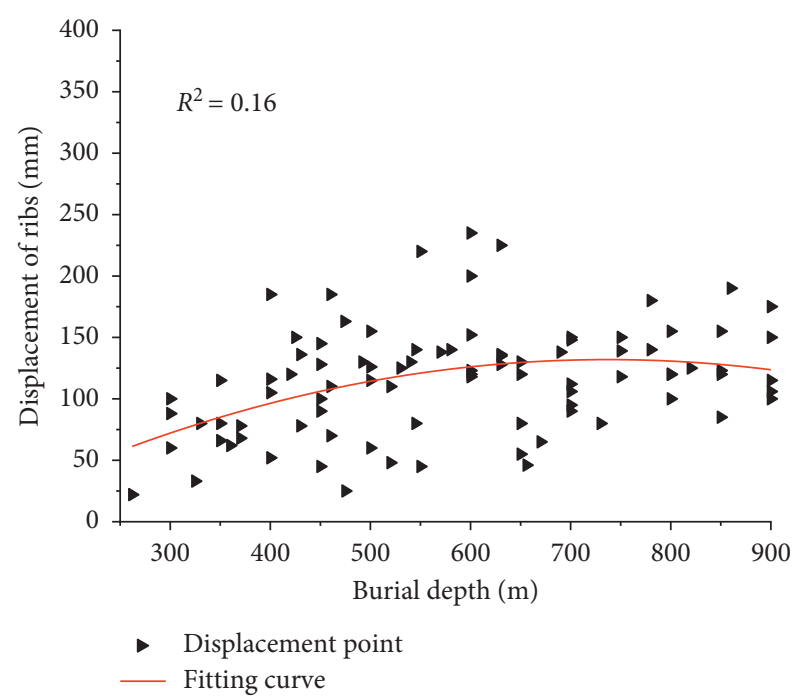

Figure 10: Displacement of ribs $\left(15^{\text {th }}\right.$ day).

$95.7 \mathrm{~mm}$. The difference value between $600 \mathrm{~m}$ and $900 \mathrm{~m}$ depth is $57.5 \mathrm{~mm}$, which is $38.2 \mathrm{~mm}$ less than the difference value between $300 \mathrm{~m}$ and $600 \mathrm{~m}$ depth.

\section{Analysis of Roadway Deformation during Mining}

4.1. Displacement of Mining Roadway Roof to Floor. The roadway deformation data within $100 \mathrm{~m}$ away from working face to monitoring points were collected.

As shown in Figures 17 and 18, when the working face is $80 \mathrm{~m}$ and $60 \mathrm{~m}$ away from the monitoring point, the

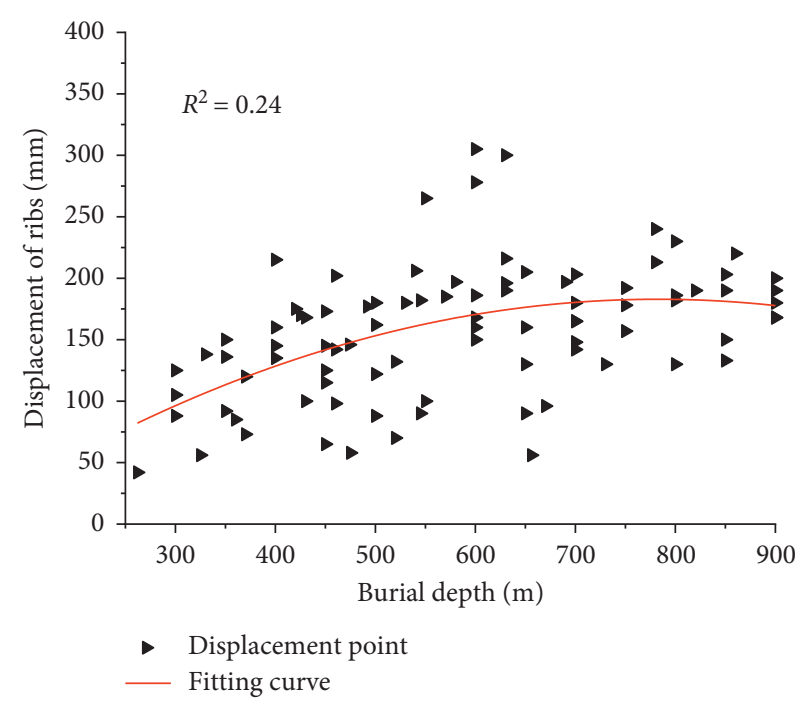

Figure 11: Displacement of ribs $\left(25^{\text {th }}\right.$ day).

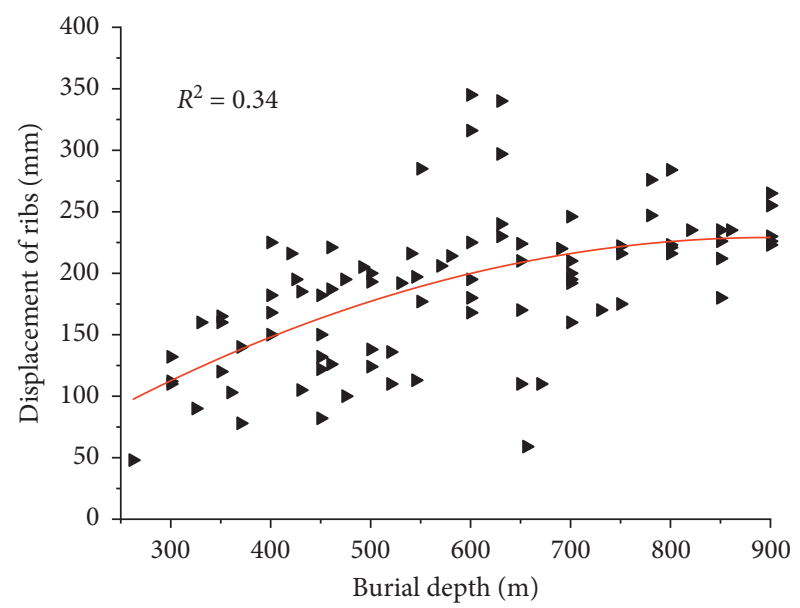

- Displacement point

- Fitting curve

Figure 12: Displacement of ribs ( $35^{\text {th }}$ day).

displacement of roadway roof to floor is $20 \sim 60 \mathrm{~mm}$ and $35 \sim 115 \mathrm{~mm}$, respectively. The relationship between the burial depth and the displacement of roof to floor is obtained: $\quad y=2.931 * 10^{-5} x^{2}+0.005 x+17.376 \quad$ and $y=8.544 * 10^{-5} x^{2}-0.005 x+44.761$.

According to the fitting curve (Figure 17), the displacement of roof to floor gradually increases with the increase in depth, while the displacement increment caused by mining is small.

As shown in Figures 19 and 20, when the working face is $40 \mathrm{~m}$ and $20 \mathrm{~m}$ away from the monitoring point, the displacement of roadway roof to floor is $75 \sim 195 \mathrm{~mm}$ and 


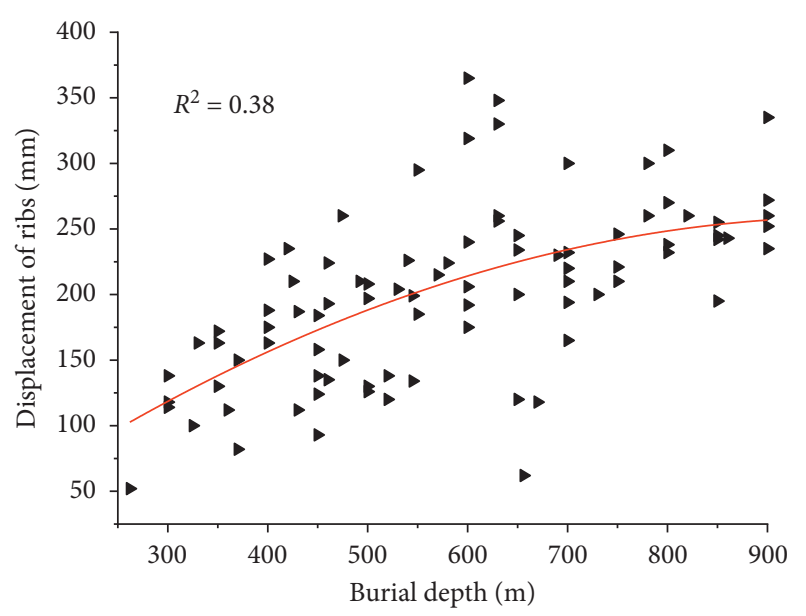

- Displacement point

— Fitting curve

FIgURE 13: Displacement of ribs $\left(45^{\text {th }}\right.$ day).

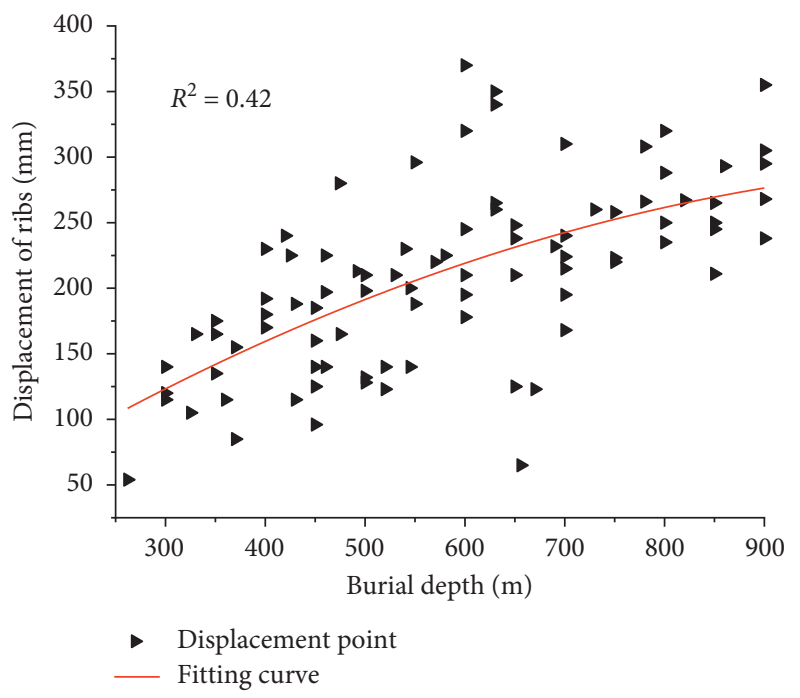

FIGURE 14: Displacement of ribs ( $50^{\text {th }}$ day).

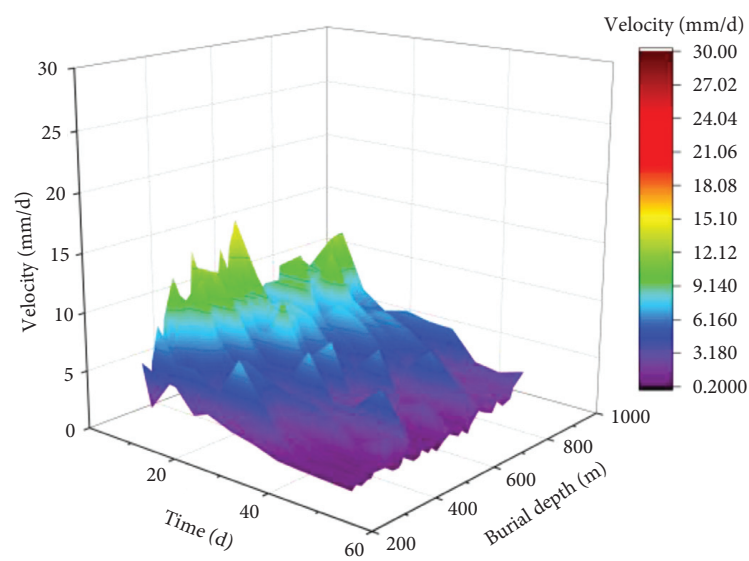

FIGURE 15: Deformation velocity of ribs.

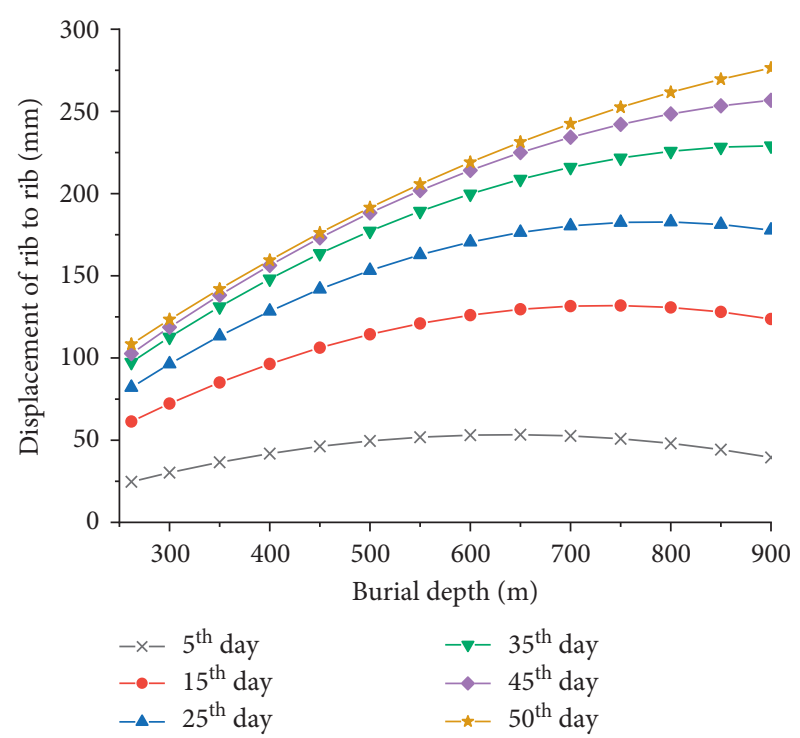

FIgURE 16: Comparison of displacement of ribs.

120 305 mm, respectively. The relationship between the buried depth and the displacement of roof to floor is obtained: $\quad y=1.172 * 10^{-4} x^{2}+0.039 x+64.963 \quad$ and $y=2.2 * 10^{-4} x^{2}+0.024 x+108.158$.

According to the result of fitting curves (Figures 19 and 20 ), as the face advances, the increase in displacement increment of roof to floor is accomplished with the increase in buried depth.

As shown in Figure 21, the displacement of roof to floor $10 \mathrm{~m}$ away from the working face is $175 \sim 425 \mathrm{~mm}$. The relationship between the buried depth and the displacement of roof to floor is obtained: $y=3.527 * 10^{-4} x^{2}-0.009 x+163.026$.

According to the result of the fitting curve (Figure 21), the displacement of roof to floor with a depth of 300 400 m has a small difference. After exceeding the depth, the displacement of roof to floor increases sharply as the depth increases.

Figure 22 shows the comparison of roof to floor displacement fitting curves at the monitoring points $80 \mathrm{~m}$, $60 \mathrm{~m}, 40 \mathrm{~m}, 20 \mathrm{~m}$, and $10 \mathrm{~m}$ away from the face. The slope of the fitting curve $80 \mathrm{~m}$ away from the working face is similar to that of $60 \mathrm{~m}$. When the monitoring point is $100 \sim 60 \mathrm{~m}$ away from the face, the displacement of roof to floor is little affected by mining and burial depth. When the distance from the monitoring point to the face is less than $60 \mathrm{~m}$, the displacement of roof to floor is gradually influenced by mining and burial depth. The slope of the fitting curves gradually increases with the decrease in the distance between the monitoring point and the face. At the same time, the displacement increment of roof to floor increases with the increase in depth.

According to the fitting curve quadratic polynomial, the final displacement of roof to floor $10 \mathrm{~m}$ away from the working face was calculated, as shown in Table 3.

As can be seen from Table 3, the difference value of roof to floor displacement between $300 \mathrm{~m}$ and $600 \mathrm{~m}$ depth is $92.5 \mathrm{~mm}$. The difference value of roof to floor displacement 
TABLE 2: Comparison of displacement of new digging roadway ribs.

\begin{tabular}{|c|c|c|c|c|c|c|c|c|c|c|c|c|}
\hline Depth $(\mathrm{m})$ & 300 & & 400 & & 500 & & 600 & & 700 & & 800 & 900 \\
\hline Displacement of rib to rib $(\mathrm{mm})$ & 123.2 & & 159.4 & & 191.3 & & 218.9 & & 242.3 & & 261.5 & 276.4 \\
\hline Difference value $(\mathrm{mm})$ & & 36.2 & & 31.9 & & 27.6 & & 23.7 & & 19.2 & & \\
\hline
\end{tabular}

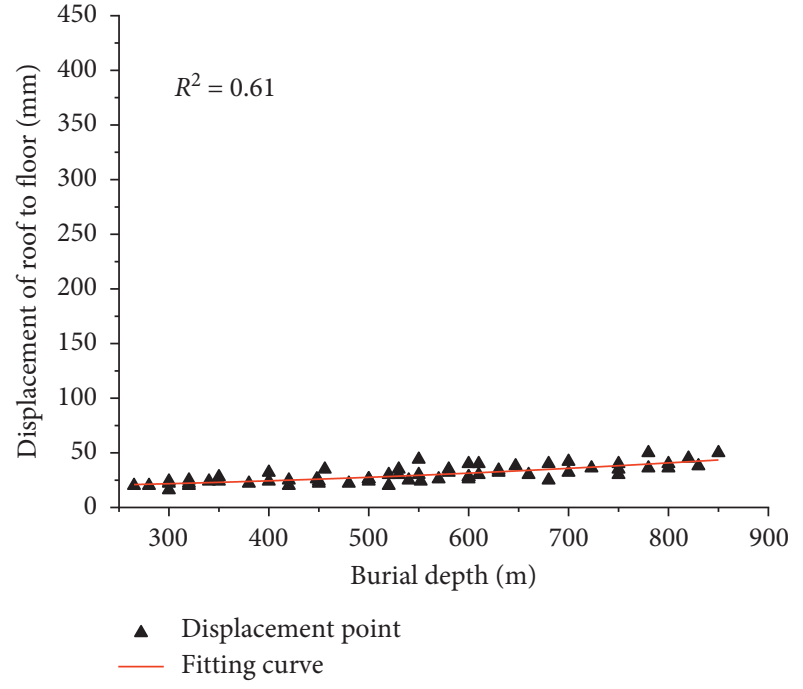

FIGURE 17: $80 \mathrm{~m}$ away from the working face.

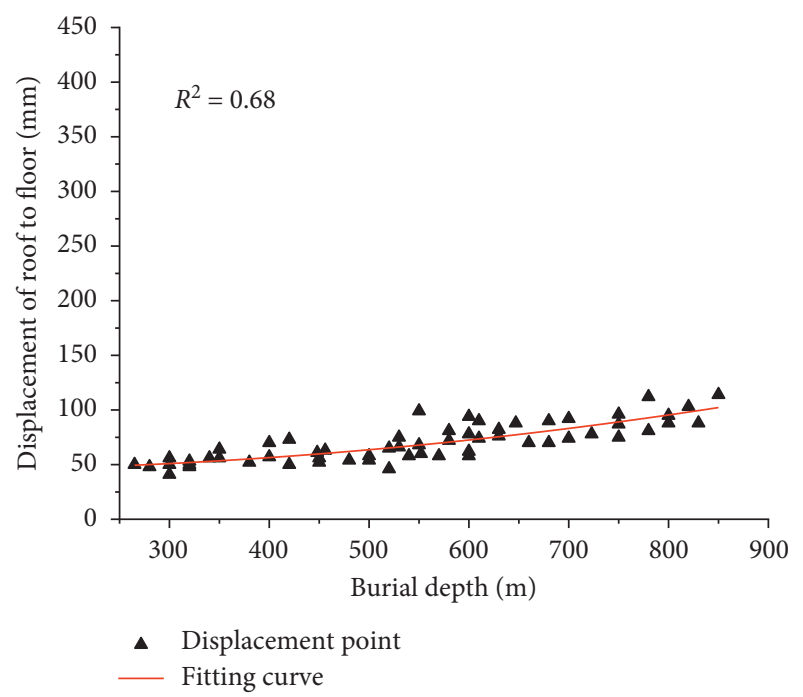

Figure 18: $60 \mathrm{~m}$ away from the working face.

between $600 \mathrm{~m}$ and $900 \mathrm{~m}$ depth is $156 \mathrm{~mm}$, which is $63.5 \mathrm{~mm}$ more than that of $600 \mathrm{~m}$ and $900 \mathrm{~m}$ depth. The displacement increment of roof to floor increases with the increase in depth.

4.2. Displacement of Mining Roadway Ribs. As shown in Figures 23 and 24, when the working face is $80 \mathrm{~m}$ and $60 \mathrm{~m}$ away from the monitoring point, the displacement of roadway rib to $\mathrm{rib}$ is $20 \sim 60 \mathrm{~mm}$ and $55 \sim 140 \mathrm{~mm}$, respectively. The relationship between the buried depth and

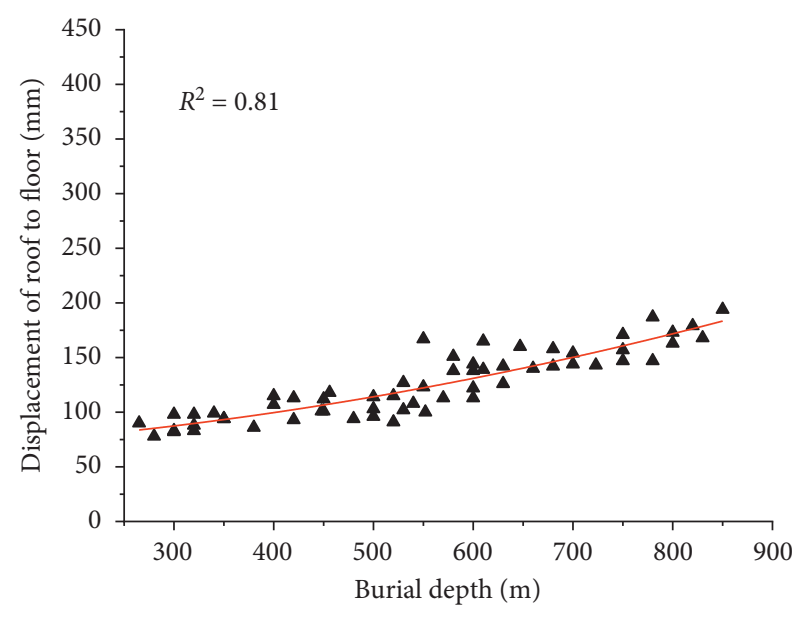

- Displacement point - Fitting curve

Figure 19: $40 \mathrm{~m}$ away from the working face.

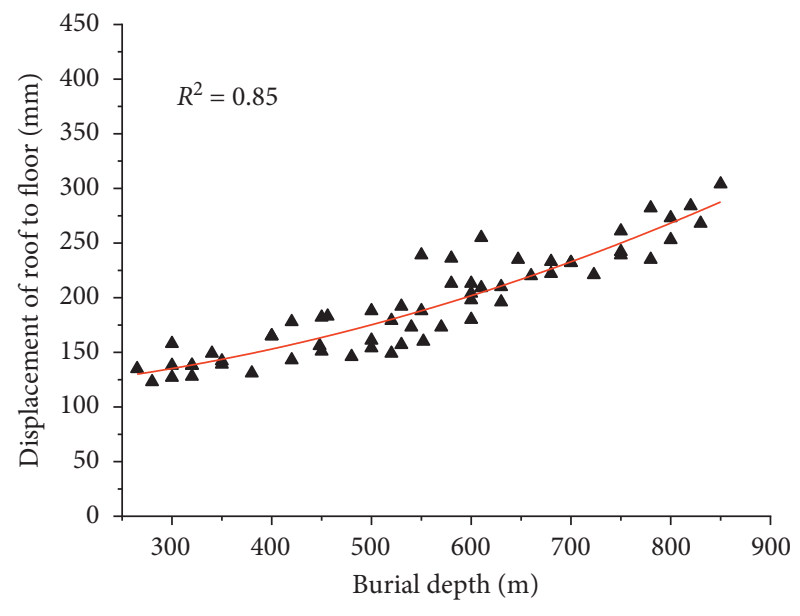

- Displacement point Fitting curve

Figure 20: $20 \mathrm{~m}$ away from the working face.

the displacement of rib to rib is obtained: $y=2.791 * 10^{-6} x^{2}+0.044 x+17.68$ and $y=2.345 * 10^{-5} x^{2}+$ $0.085 x+44.73$.

According to the result of the fitting curve (Figure 23), with the increase in the buried depth, the displacement of ribs gradually increases, while the displacement increment is little affected by mining.

As shown in Figures 25 and 26, when the working face is $40 \mathrm{~m}$ and $20 \mathrm{~m}$ away from the monitoring point, the displacement of ribs is $95 \sim 225 \mathrm{~mm}$ and $145 \sim 330 \mathrm{~mm}$, 


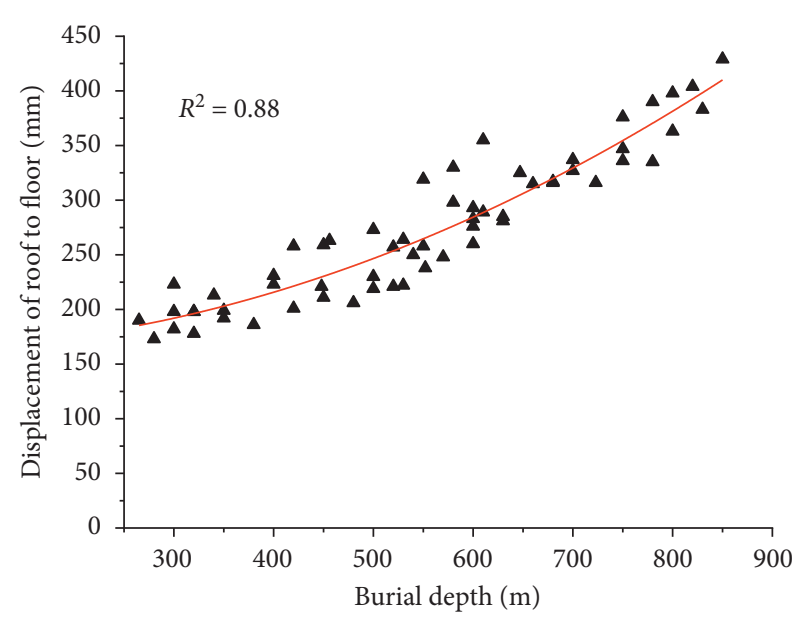

\ Displacement point - Fitting curve

FIGURE 21: $10 \mathrm{~m}$ away from the working face.

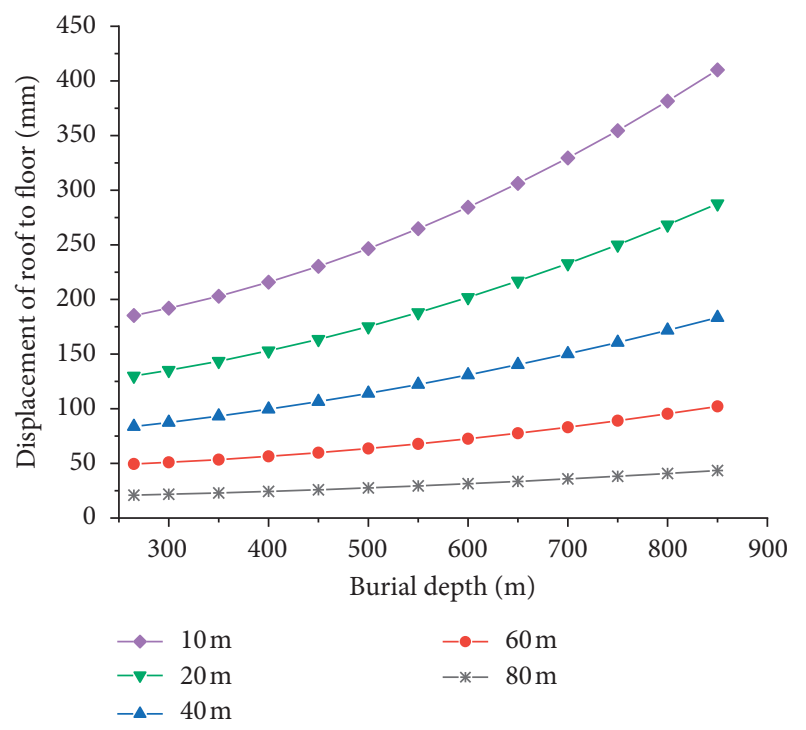

Figure 22: Comparison of displacement of roof to floor.

respectively. The relationship between the buried depth and the displacement of ribs is obtained: $y=8.249 * 10^{-5} x^{2}+$ $0.069 x+93.766$ and $y=2.992 * 10^{-4} x^{2}-0.076 x+171.313$.

According to the results of the fitting curve (Figures 25 and 26), as the working face advances, the displacement increment of ribs gradually increases with the increase in the depth.

As shown in Figure 27, when the working face is $10 \mathrm{~m}$ away from the monitoring point, the displacement of ribs is 200 450 $\mathrm{mm}$. The relationship between the buried depth and the displacement of ribs is obtained: $y=4.942 * 10^{-4} x^{2}-0.187 x+224.796$

According to the results of the fitting curve (Figure 27), when the depth is between 300 and $400 \mathrm{~m}$, the displacement of ribs is similar. After exceeding this range, the displacement of ribs increases sharply with the increase in depth.
Figure 28 shows the comparison of ribs displacement fitting curves at the monitoring points $80 \mathrm{~m}, 60 \mathrm{~m}, 40 \mathrm{~m}$, $20 \mathrm{~m}$, and $10 \mathrm{~m}$ away from the face. The slope of the fitting curve $80 \mathrm{~m}$ away from the working face is similar to that of $60 \mathrm{~m}$. When the face is $100 \sim 60 \mathrm{~m}$ away from the monitoring point, the displacement of ribs is little affected by mining and burial depth. When the distance from the monitoring point to the face is less than $60 \mathrm{~m}$, the displacement of ribs is gradually influenced by mining and burial depth. The slope of the fitting curves gradually increases with the decrease in the distance between the monitoring point and the face. At the same time, the displacement increment of ribs increases with the increase in depth.

According to the fitting curve quadratic polynomial, the final displacement of ribs $10 \mathrm{~m}$ away from the working face was calculated, as shown in Table 4.

As can be seen from Table 4, the difference value of ribs displacement between $300 \mathrm{~m}$ and $600 \mathrm{~m}$ depth is $77.3 \mathrm{~mm}$. The difference value of ribs displacement between $600 \mathrm{~m}$ and $900 \mathrm{~m}$ depth is $233.7 \mathrm{~mm}$, which is $156.4 \mathrm{~mm}$ more than the difference value between $600 \mathrm{~m}$ and $900 \mathrm{~m}$ depth. The displacement increment of ribs increases with the increase in depth.

To sum up, the deformation of roadway surrounding rock within $100 \mathrm{~m}$ away from the face shows the following laws:

(1) Within the range of $100 \sim 60 \mathrm{~m}$ away from the working face, the deformation of the roadway surrounding rock increases slightly with the decrease in the distance from the face to the monitoring point. At the same, the displacement increment of surrounding rock increases gradually with the increase in depth. This range is the stable range affected by mining

(2) Within the range of 60 10 $\mathrm{m}$ away from the working face, the deformation of roadway surrounding rock with the same buried depth increases sharply with the decrease in the distance between the face to the monitoring point. The displacement increment of surrounding rock increases with the increase in depth. The deformation of surrounding rock increases sharply with the face advances. This range is the severe range affected by mining.

(3) After the buried depth exceeds $600 \mathrm{~m}$, the buried depth has a great effect on the deformation of roadway surrounding rock.

\section{Analysis of the Causes of Roadway Deformation}

Experts and scholars generally believe that the instability of roadway surrounding rock is caused by the insufficient bearing capacity and supporting force of surrounding rock. Therefore, they focus on the study of supporting structure and ignore the analysis of the bearing capacity of surrounding rock itself. The bearing capacity of roadway free face to different areas in the deep surrounding rock is different [16]. 
TABLE 3: Comparison of the final displacement of mining roadway roof to floor.

\begin{tabular}{|c|c|c|c|c|c|c|c|c|c|c|c|c|}
\hline Depth $(\mathrm{m})$ & 300 & & 400 & & 500 & & 600 & & 700 & & 800 & 900 \\
\hline Displacement of roof to floor $(\mathrm{mm})$ & 192.1 & & 215.9 & & 246.7 & & 284.6 & & 329.5 & & 381.5 & 440.6 \\
\hline Difference value $(\mathrm{mm})$ & & 23.8 & & 30.8 & & 37.9 & & 44.9 & & 52 & & \\
\hline
\end{tabular}

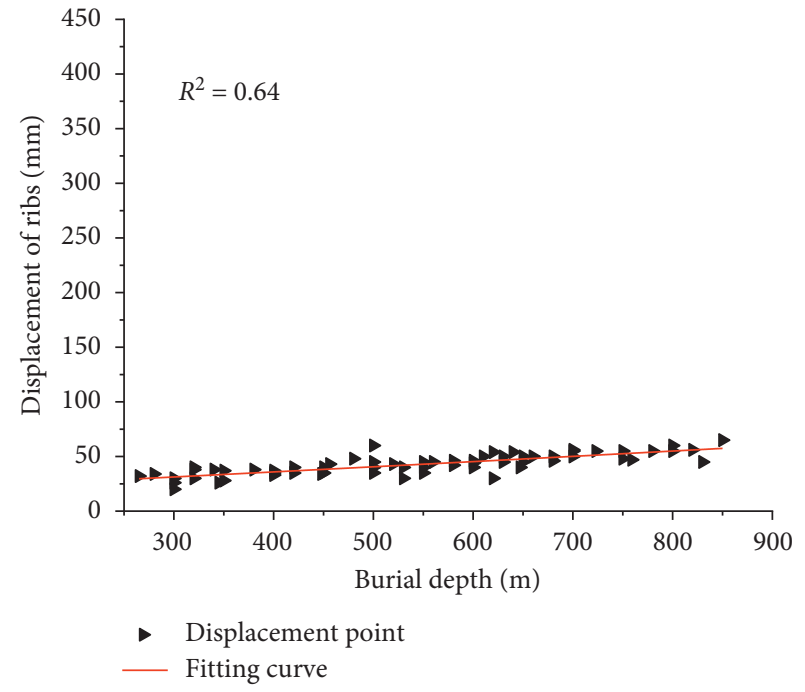

Figure 23: $80 \mathrm{~m}$ away from the working face.

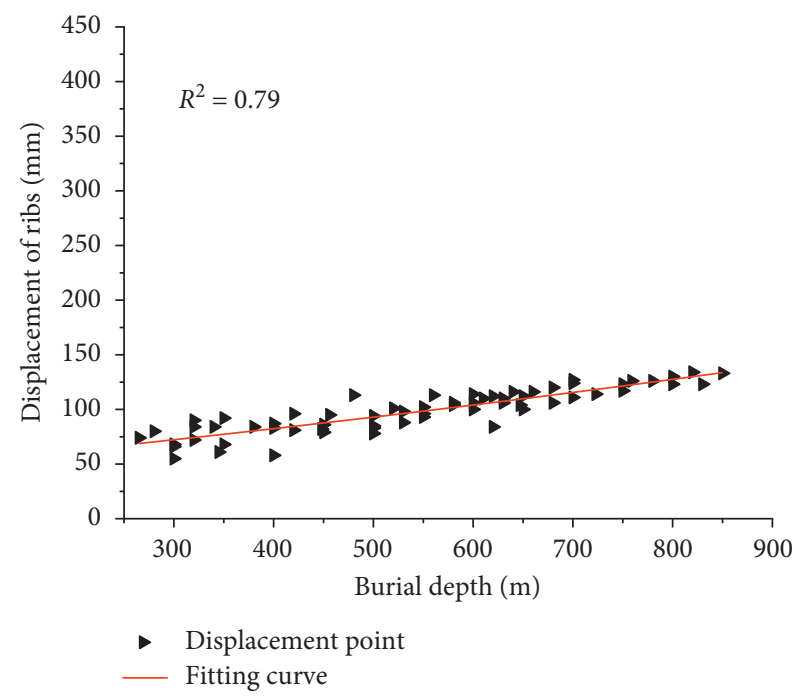

Figure 24: $60 \mathrm{~m}$ away from the working face.

5.1. Correlation between Roadway Deformation and In Situ Stress. In situ stress is the essential force of rock deformation and failure, and it is the precondition for stability analysis of surrounding rock [17]. In 1926, the Soviet scholar A. H. Dinnik revised Heim's hydrostatic pressure hypothesis, believing that the vertical stress at each point in the crust is equal to the weight of the overlying strata. The lateral stress (horizontal stress) is the result of the Poisson effect, regardless of tectonic stress, and this value should be $\gamma H$ multiplying a correction factor. According to the theory of

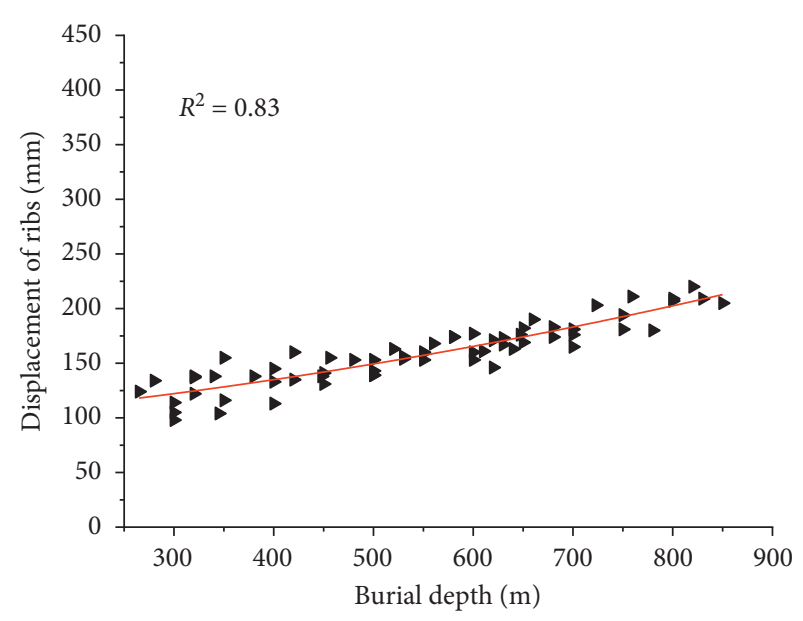

- Displacement point

- Fitting curve

Figure 25: $40 \mathrm{~m}$ away from the working face.

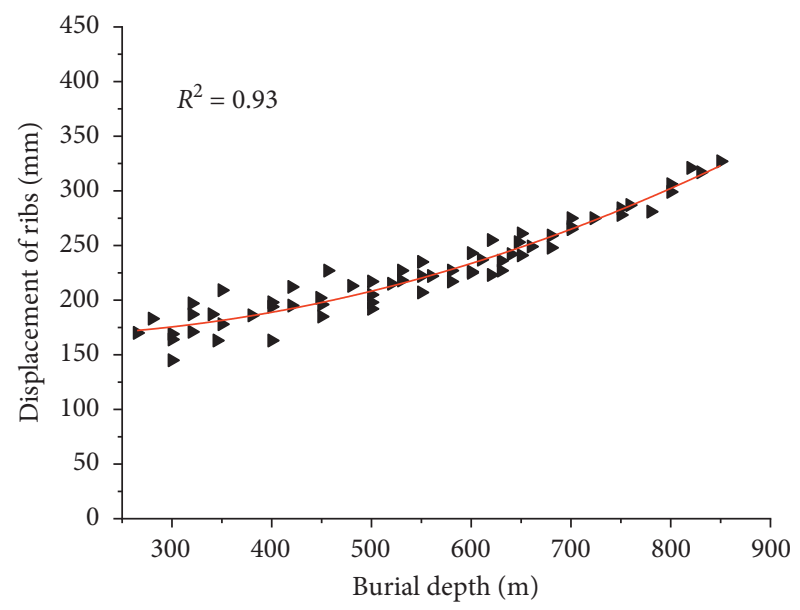

- Displacement point

- Fitting curve

FIgURE 26: $20 \mathrm{~m}$ away from the working face.

elastic mechanics, he thought that this coefficient is equal to $v /(1-v)$ and obtained the relationship between burial depth and in situ stress:

$$
\begin{aligned}
\sigma_{v} & =\gamma H, \\
\sigma_{h} & =\frac{v}{1-v} \gamma H,
\end{aligned}
$$

where $\sigma_{v}$ is vertical stress; $\sigma_{h}$ is horizontal stress; $\gamma$ is overlying strata bulk density; $H$ is burial depth; and $v$ is the Poisson rate of overlying strata. 


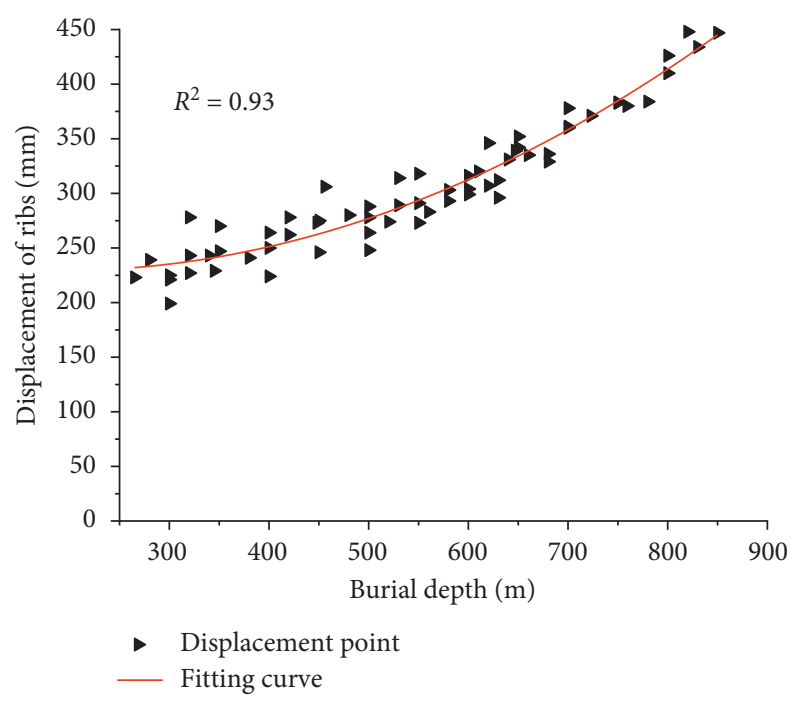

FIGURE 27: $10 \mathrm{~m}$ away from the working face.

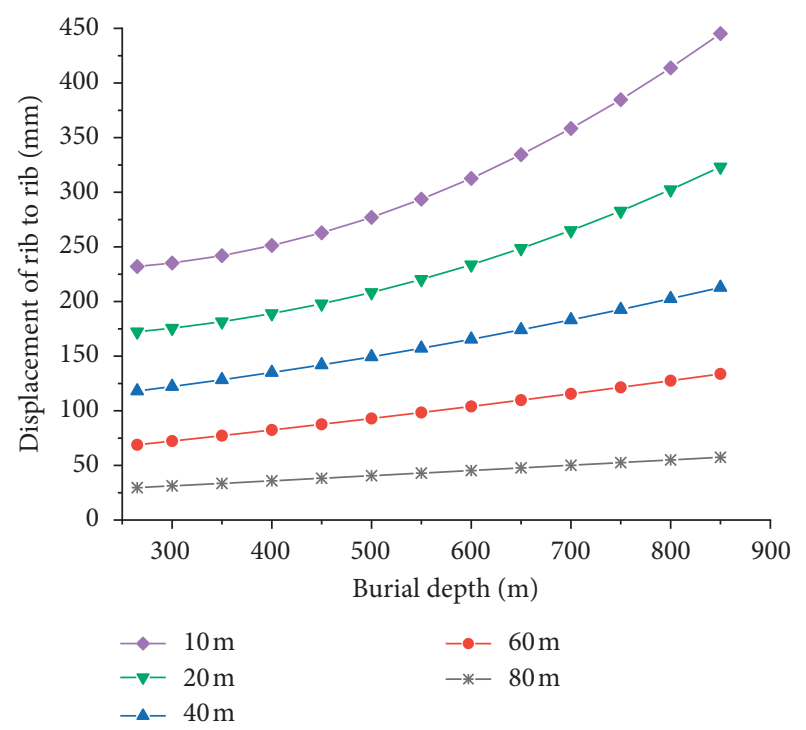

FIgURE 28: Comparison of displacement of ribs.

Due to a large amount of roadway deformation data and complicated classification, we simplified the analysis process of roof and floor lithology, so as to reflect the surface deformation law of roadway more directly. It is found that the surrounding rock of nearly 100 roadways is mainly composed of four representative types of rock: siltstone, mudstone, fine sandstone, and sandy mudstone, and their proportions are shown in Figure 29. According to the above calculation formula and rock mechanics parameters, assuming that the average bulk weight of overlying strata is $2400 \mathrm{~kg} / \mathrm{m}^{3}$, the rock parameters are substituted into the formula to estimate the buried depth and in situ stress values corresponding to each rock strength, as shown in Table 5.

As can be seen from Table 5, after the burial depth exceeds $400 \sim 500 \mathrm{~m}$, the in situ stress is close to the limit value of cohesion of most roadway rock.
The surrounding rock deformation data of the new digging roadway were classified according to different lithology, and the deformation curves of surrounding rock were obtained under different surrounding rock conditions. As shown in Figures 30 and 31, at the same buried depth, the deformation of the siltstone roadway is the smallest, while that of the mudstone is the largest. The slope of deformation curves decreases with the increase in buried depth.

Table 6 shows the displacement of mudstone roadway ribs with different buried depths. The displacement increment of ribs with different depths decreases gradually with the increase in buried depth. The difference value of ribs displacement between $300 \mathrm{~m}$ and $600 \mathrm{~m}$ depth is $172.5 \mathrm{~mm}$. The difference value of ribs displacement between $600 \mathrm{~m}$ and $900 \mathrm{~m}$ depth is $59.9 \mathrm{~mm}$, which is $112.6 \mathrm{~mm}$ less than the difference value of $300 \mathrm{~m} \sim 600 \mathrm{~m}$ depth.

As shown in Figures 32 and 33, the deformation of surrounding rock increases with the increase in roadway width and height. The slope of roadway deformation curves decreases with the increase in buried depth, which indicates that the effect of burial depth on the deformation of surrounding rock is gradually weakened.

The ribs displacement curve with the roadway width of 3.5 4 m was taken to obtain the rib to rib displacement of the roadway corresponding to different depths, as shown in Table 7.

As shown in Table 7, the deformation difference between the ribs decreases gradually with the increase in depth. The difference value of ribs displacement between $300 \mathrm{~m}$ and $600 \mathrm{~m}$ depth is $115.8 \mathrm{~mm}$. The difference value of ribs displacement between $600 \mathrm{~m}$ and $900 \mathrm{~m}$ depth is $41.8 \mathrm{~mm}$, which is $74 \mathrm{~mm}$ less than that of $300 \mathrm{~m} \sim 600 \mathrm{~m}$ depth.

In the above estimation, after the buried depth exceeds $400 \sim 500 \mathrm{~m}$, the in situ stress is close to the limiting strength of most roadway rock. However, in the actual deformation data, the limiting depth of roadway rock strength is $600 \mathrm{~m}$. This is because the rock mechanics parameters used to estimate the buried depth of rock limiting strength are measured under the uniaxial test, while the actual stress condition of surrounding rock is three-axis, so the buried depth of limiting strength has errors.

5.2. Causes of Roadway Deformation during Digging and Mining. After roadway excavation, with the increase in buried depth (especially over $600 \mathrm{~m}$ ), the deformation increment between roadways gradually decreases (see Figures 6 and 14). This is because the increase in buried depth (in situ stress) exceeds the limit of the cohesive force of rock mass, making the surrounding rock gradually transform from brittleness to ductility [18] and reducing the deformation energy of rock. Under the action of the reasonable support structure of roadway, the deformation of surrounding rock is controlled within the controllable range and finally tends to be stable.

In the mining stage of the working face, the roadway deformation increases gradually with the decrease in the distance between face and the monitoring point, and the 
TABLE 4: Comparison of the final displacement of mining roadway ribs.

\begin{tabular}{|c|c|c|c|c|c|c|c|c|c|c|c|c|}
\hline Depth (m) & 300 & & 400 & & 500 & & 600 & & 700 & & 800 & 900 \\
\hline Displacement of rib to rib $(\mathrm{mm})$ & 213.2 & & 229.1 & & 254.8 & & 290.5 & & 336.1 & & 391.5 & 456.8 \\
\hline Difference value $(\mathrm{mm})$ & & 15.9 & & 25.7 & & 35.7 & & 45.6 & & 55.4 & & \\
\hline
\end{tabular}

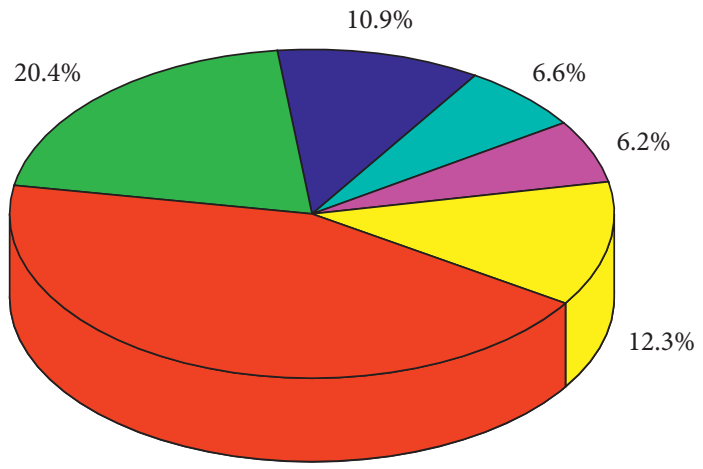

$43.6 \%$

Mudstone

$\square$ Fine stone

Sandy mudstone

Siltstone

Charcoal stone

Others

FIgURE 29: The pie chart of surrounding rock lithology.

TABLE 5: Limiting strength and buried depth of rock.

\begin{tabular}{|c|c|c|c|c|}
\hline Lithology & Siltstone & Mudstone & Fine sandstone & Sandy stone \\
\hline Buried depth of limiting strength $(\mathrm{m})$ & $500 \sim 600$ & $300 \sim 400$ & $400 \sim 500$ & $400 \sim 500$ \\
\hline Cohesion range $(\mathrm{MPa})$ & $11.5 \sim 12.5$ & $6 \sim 7$ & $9 \sim 10$ & 7 8 \\
\hline
\end{tabular}

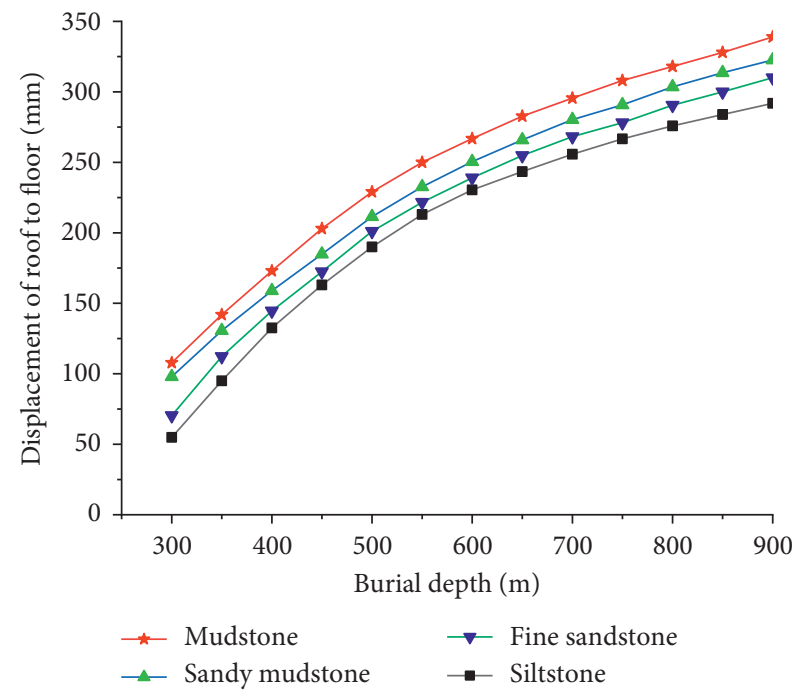

Figure 30: Displacement of roof to floor.

roadway deformation increment increases gradually with the increase in the depth. This is because the front pressure double increases in the process of the face advance. Meanwhile, the original support structure fails to control the

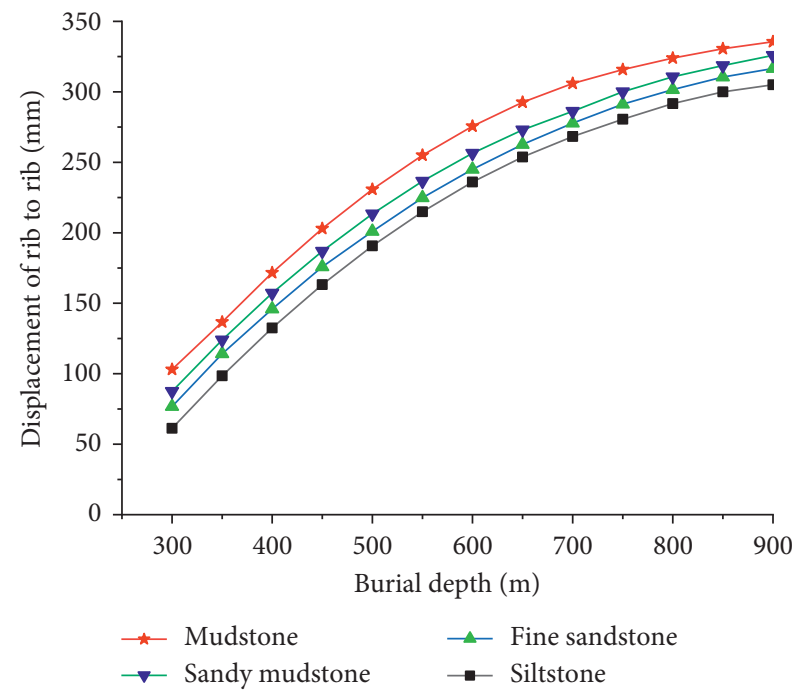

Figure 31: Displacement of ribs.

deformation of surrounding rock. As a result, the deformation increment of surrounding rock gradually increases with the increase in depth in the process of the face advance. 
TABLE 6: Comparison of displacement of new digging roadway ribs (mudstone).

\begin{tabular}{lcccccccc}
\hline Depth $(\mathrm{m})$ & 300 & 400 & 500 & 600 & & 700 & 800 & 900 \\
\hline $\begin{array}{l}\text { Displacement of rib to rib (mm) } \\
\text { Difference value (mm) }\end{array}$ & 103.1 & 171.6 & 230.8 & 275.6 & & 305.9 & 323.9 & 335.5 \\
\hline
\end{tabular}

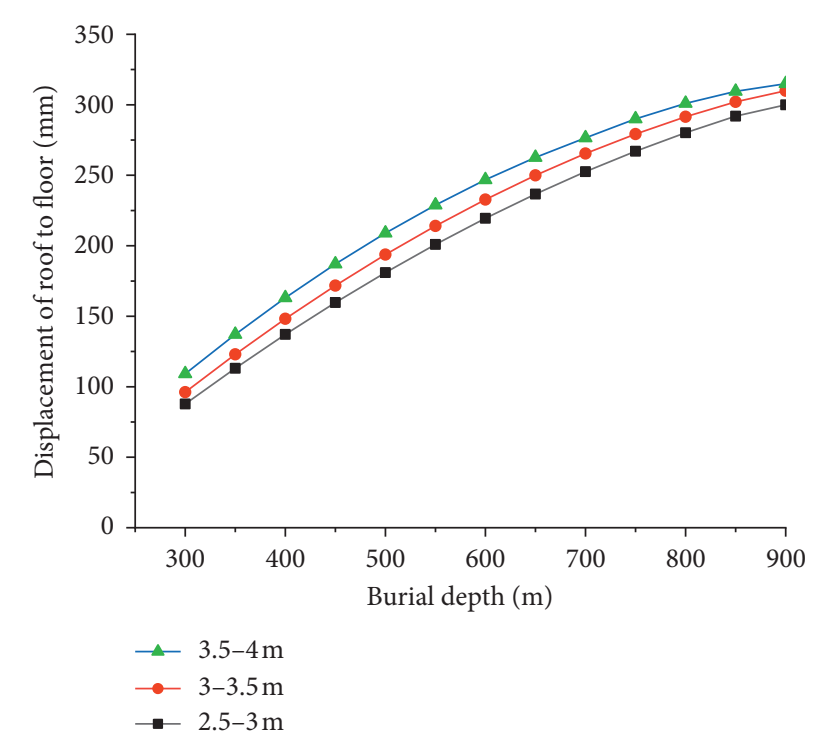

Figure 32: Displacement of roof to floor with different widths.

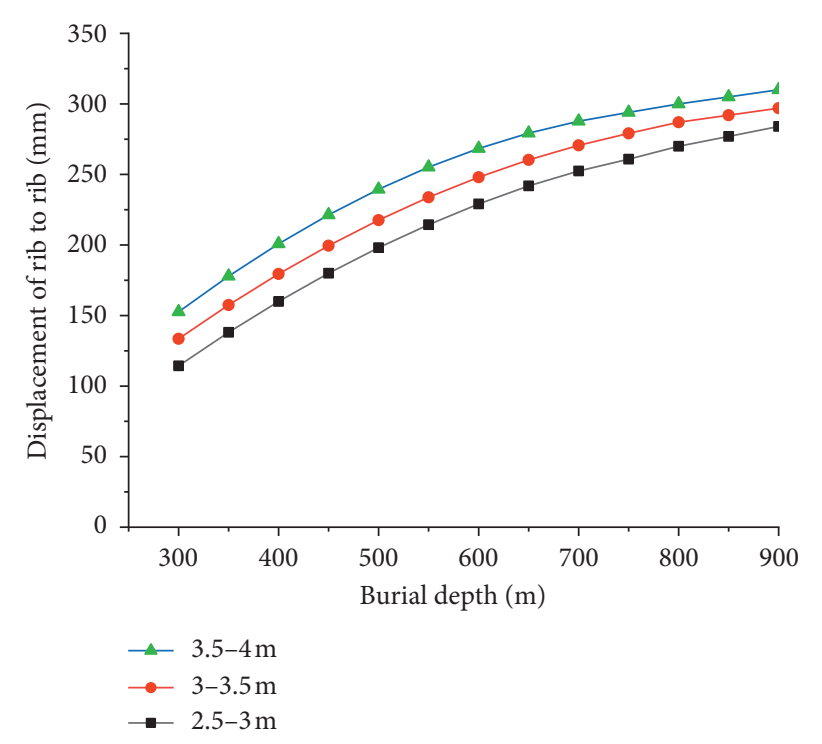

FIgURE 33: Displacement of rib to rib with different heights.

TABle 7: Comparison of displacement of new digging roadway rib to rib.

\begin{tabular}{|c|c|c|c|c|c|c|c|c|c|c|c|c|}
\hline Depth $(\mathrm{m})$ & 300 & & 400 & & 500 & & 600 & & 700 & & 800 & 900 \\
\hline Displacement of rib to rib (mm) & 152.6 & & 200.8 & & 239.4 & & 268.4 & & 287.7 & & 300.4 & 310.2 \\
\hline Difference value $(\mathrm{mm})$ & & 48.2 & & 38.6 & & 29 & & 19.3 & & 12.7 & & \\
\hline
\end{tabular}




\section{Conclusions}

(1) In the first 5 days after the roadway excavation, the surrounding rock deformation is basically not affected by the buried depth. The influence period of roadway deformation with different depths is the same. Within 50 days after roadway excavation, $1 \sim 15$ days is a severe period, 15 35 days is a moderating period, and 35 50 days is a stable period.

(2) With the increase in buried depth, the deformation increment of new digging roadways decreases gradually. The deformation increment of surrounding rock with buried depth within $300 \sim 600 \mathrm{~m}$ is about twice 600 900 $\mathrm{m}$. The buried depth of the limiting strength of most roadway surrounding rock is $600 \mathrm{~m}$.

(3) In the range of $100 \mathrm{~m}$ from the working face to the monitoring point, the surrounding rock deformation is affected by the front pressure of the face, which can be divided into two stages: severe influence range $(10 \sim 60 \mathrm{~m})$ and stable influence range $(60 \sim 100 \mathrm{~m})$. With the increase in buried depth, the deformation increment of mining roadway with buried depth within $600 \sim 900 \mathrm{~m}$ is much larger than that within 300 600 m.

(4) The deformation of surrounding rock increases with the increase in the width and height of the roadway section and increases with the decrease in the strength of surrounding rock.

\section{Data Availability}

The data were obtained from the CNKI database.

\section{Conflicts of Interest}

The authors declare no conflicts of interest.

\section{Authors' Contributions}

Hai Wu and Xiaokang Wang contributed equally to this paper. Conceptualization was performed by W. H. and W. X. K.; methodology was proposed by W. H.; software was provided by W. X. K.; validation was done by W. H., W. X. K., and Z. Z. Z.; resources were provided by $\mathrm{W}$. W. J. and Y. W. J.; original draft was prepared by W. X. K.; and reviewing and editing were done by W. H.

\section{Acknowledgments}

The authors gratefully acknowledge the funding for this work provided by the National Natural Science Foundation of China (nos. 51774133, 52074117, 51804111, and 51804109) and Hunan Provincial Natural Science Foundation of China (no. 2020JJ4305).

\section{References}

[1] W. T. Li, S. C. Li, C. Xuan, Q. Wang, X. Wang, and X. Shao, "Mechanism and control of failure of rock roadway support in highly stressed soft rock," Chinese Journal of Rock Mechanics and Engineering, vol. 34, pp. 1836-1848, 2015.
[2] H. Lan, D. K. Chen, and D. B. Mao, "Current status of deep mining and disaster prevention in China," Coal Science and Technology, vol. 44, pp. 39-46, 2016.

[3] M. C. He, H. P. Xie, S. P. Peng, and Y. D. Jiang, "Study on rock mechanics in deep mining engineering," Chinese Journal of Rock Mechanics and Engineering, vol. 24, pp. 2803-2813, 2005.

[4] M. C. He, "Progress and challenges of soft rock engineering in depth," Journal of China Coal Society, vol. 39, pp. 1409-1417, 2014.

[5] H. Wu, X. Wang, W. Wang, G. Peng, and Z. Zhang, "Deformation characteristics and mechanism of deep subsize coal pillar of the tilted stratum," Energy Science \& Engineering, vol. 8, no. 2, pp. 544-561, 2020.

[6] J. B. Bai, W. J. Wang, C. J. Hou, and H. F. Huang, "Control mechanism and support technique about gateway driven along goaf in fully mechanized top coal caving face," Journal of China Coal Society, vol. 25, pp. 478-481, 2000.

[7] J. X. Kang, Y. L. Wang, G. J. Shu, Z. Y. Dai, and S. Liu, "Mechanism and control of failure for surrounding rock in highly stressed "three soft" coal seam mining roadway," Journal of Mining \& Safety Engineering, vol. 35, pp. 449-456, 2018.

[8] G. C. Li, "Study on the surrounding rock stability and safety control of roadways roof embedded weak intercalated seam," China University of Mining and Technology, Xuzhou, China, Doctoral thesis, 2008.

[9] W. J. Yu, W. J. Wang, G. H. Wen, N. Zhang, H. Wu, and Y. Q. Zhang, "Deformation mechanism and control technology of coal roadway under deep well and compound roof," Chinese Journal of Geotechnical Engineering, vol. 34, pp. 1501-1508, 2012.

[10] H. Wu, "Research on asymmetrical deformation laws and stability control of deep inclined rock strata roadway," China University of Mining and Technology, Xuzhou, China, Doctoral thesis, 2014.

[11] H. P. Kang, Y. Z. Wu, J. He, and J. K. Fu, "Rock bolting performance and field practice in deep roadway with rock burst," Journal of China Coal Society, vol. 40, pp. 2225-2233, 2015.

[12] W. J. Wang, C. Yuan, W. J. Yu et al., "Stability control method of surrounding rock in deep roadway with large deformation," Journal of China Coal Society, vol. 41, pp. 2921-2931, 2016.

[13] J. B. Bai, W. F. Li, X. Y. Wang, Y. Xu, and L. J. Huo, "Mechanism of floor heave and control technology of roadway induced by mining," Journal of Mining \& Safety Engineering, vol. 28, pp. 1-5, 2011.

[14] N. J. Ma, X. D. Zhao, Z. Q. Zhao, J. Li, and X. F. Guo, "Stability analysis and control technology of mine roadway roof in deep mining," Journal of China Coal Society, vol. 40, pp. 2287-2295, 2015.

[15] W. J. Yu, T. Feng, W. J. Wang et al., "Deformation mechanism, control principle and technology of soft half coal rock roadway," Chinese Journal of Rock Mechanics and Engineering, vol. 33, pp. 658-671, 2014.

[16] C. Wang, Y. Wang, and S. Lu, "Deformational behaviour of roadways in soft rocks in underground coal mines and principles for stability control," International Journal of Rock Mechanics and Mining Sciences, vol. 37, no. 6, pp. 937-946, 2000.

[17] M. F. Cai, Rock Mechanics and Engineering, Science Press, Beijing, China, 2002.

[18] C. Zhang, W. G. Cai, and J. Y. Wang, "A study of the statistical damage constitutive model for the brittle-ductile transition of rock with consideration of damage threshold," Hydrogeology \& Engineering Geology, vol. 40, pp. 45-50, 2013. 